\title{
Precipitation Trends over Time Using Mann-Kendall and Spearman's rho Tests in Swat River Basin, Pakistan
}

\author{
Ijaz Ahmad, ${ }^{1}$ Deshan Tang, ${ }^{1}$ TianFang Wang, ${ }^{2}$ Mei Wang, ${ }^{1}$ and Bakhtawar Wagan' \\ ${ }^{1}$ College of Water Conservancy and Hydropower Engineering, Hohai University, Nanjing 210098, China \\ ${ }^{2}$ School of Earth Science and Engineering, Hohai University, Nanjing 210098, China \\ Correspondence should be addressed to Ijaz Ahmad; engr.ijaz786@gmail.com
}

Received 14 October 2014; Revised 12 December 2014; Accepted 16 December 2014

Academic Editor: Harry D. Kambezidis

Copyright (c) 2015 Ijaz Ahmad et al. This is an open access article distributed under the Creative Commons Attribution License, which permits unrestricted use, distribution, and reproduction in any medium, provided the original work is properly cited.

\begin{abstract}
Accurately predicting precipitation trends is vital in the economic development of a country. This research investigated precipitation variability across 15 stations in the Swat River basin, Pakistan, over a 51-year study period (1961-2011). Nonparametric MannKendall (MK) and Spearman's rho (SR) statistical tests were used to detect trends in monthly, seasonal, and annual precipitation, and the trend-free prewhitening approach was applied to eliminate serial correlation in the precipitation time series. The results highlighted a mix of positive (increasing) and negative (decreasing) trends in monthly, seasonal, and annual precipitation. One station in particular, the Saidu Sharif station, showed the maximum number of significant monthly precipitation events, followed by Abazai, Khairabad, and Malakand. On the seasonal time scale, precipitation trends changed from the summer to the autumn season. The Saidu Sharif station revealed the highest positive trend $(7.48 \mathrm{~mm} /$ year) in annual precipitation. In the entire Swat River basin, statistically insignificant trends were found in the subbasins for the annual precipitation series; however, the Lower Swat subbasin showed the maximum quantitative increase in the precipitation at a rate of $2.18 \mathrm{~mm} /$ year. The performance of the MK and SR tests was consistent at the verified significance level.
\end{abstract}

\section{Introduction}

Rainfall and other precipitation levels are important factors affecting crop selection and ecological changes in a region. Accurately predicting precipitation trends can play an important role in a country's future economic development.

Rahman and Begum [1] noted that predicting trends using precipitation time series data is more difficult than predicting temperature trends. The fourth Intergovernmental Panel on Climate Change (IPCC) reported temporal and spatial variation in precipitation trends throughout the latter half of the century across Asia [2]. Recently, meteorologists and other researchers worldwide have paid significant attention to analyzing precipitation time series trends. Decreasing trends in mean annual rainfall have been found in the coastal and arid plains of Pakistan [3], Northeast and North China [4, 5], Madhya Pradesh, India [6], and Russia [7, 8]. Increasing mean annual rainfall trends were observed in the Chang Jiang valley, southeast coastal areas and Western China $[4,5,9]$, and Bangladesh in the summer season [10, 11].

Different statistical test methods are used to detect trends in hydrological and hydrometeorological time series; these are classified as parametric and nonparametric tests [12-14]. Parametric tests are more powerful but require that data be independent and normally distributed, which is rarely true for hydrological time series data. For nonparametric tests, data must be independent, but outliers are better tolerated. The most common nonparametric tests for working with time series trends are the Mann-Kendall $[15,16]$ and Spearman's rho $[17,18]$ tests. The Mann-Kendall test is the most common one used by researchers in studying hydrologic time series trends [19-23]; less common, Spearman's rho is used to detect monotonic trends in hydrometeorological data [24]. In many studies, Spearman's rho is used in combination with the Mann-Kendall test for comparison purposes [2428]. 
Natural disasters, including avalanches, cyclones and storms, droughts and floods, and cloudburst flash floods (CBFF), pose serious risks to Pakistani society [29-31]. Pakistan has faced one major flood approximately every 3 years, creating challenges for economic development [32]. In 2010, Pakistan faced the worst flood event in its history [33]. Experts from the World Climate Research Programme and World Meteorological Organization (WMO) have stated that climate change is one of the main reasons for this unprecedented sequence of weather events. A UN scientific body concluded that hot extremes, heat waves, and heavy precipitation events will likely continue to become more frequent in Pakistan; the same body warns that floods may become more frequent and intense in the future [2]. WMO has noted that the 2010 floods were consistent with the sequence predicted by climate experts, further stating that current events match projections of more frequent and intense weather events due to global warming [34].

Floods in Pakistan are generally caused by concentrated heavy precipitation in watersheds, sometimes augmented by snowmelt flows, causing river floods during the monsoon season. Hartmann and Andresky [35] reported that the precipitation regimes in northwest areas of Pakistan are mainly controlled by monsoon rains from July to September; they have become more intense in recent years. Salma et al. [36] analyzed Pakistan rainfall trends using analysis of variance (ANOVA) from 1976 to 2005 and concluded that while the overall rainfall trends have declined, rainfall consequences such as droughts and super floods have badly affected human settlements, water management, and agriculture sectors. Hanif et al. [37] found significant precipitation changes in northern parts of Pakistan during the summer and monsoon (July and August) seasons. Significant increasing trends in precipitation over time have been detected in northeast areas of Pakistan during the monsoon season [38]; Cheema and Hanif [39] detected increasing rainfall trends in the Punjab province of Pakistan. Significant increasing trends were detected in the northwest (Hindu Kush and Sulaiman Mountains) and in the east (Himalayas) areas of the Indus River basin; insignificant negative trends were found in the northeast (Karakorum and Transhimalaya) and lowland of the upper Indus River basin [35, 40].

During the last week of July 2010, unprecedented rains fell in Swat and Kabul river catchment areas, causing catastrophic floods in excess of 400,000 cusecs, exceeding the previous record flood set in 1929 (250,000 cusecs) and impacting 24 districts of the KPK province of Pakistan [32]. Due to changing weather patterns, Pakistan's KPK province and the Swat River area have been exposed to risks from frequent floods and droughts in recent years [31, 41]. Most past studies, however, have focused on climatic trend analyses in the upper Indus River basin. No precipitation trend studies have focused on the Swat River basin, which has faced frequent floods and droughts over the years. This study fills this research gap.

This study investigated trends and variations in precipitation over time at the Swat River basin in Pakistan, using Mann-Kendall and Spearman's rho tests. This study provides a broad overview of precipitation statistics, including seasonal and interannual variability over the Swat River basin, and may help managers and agricultural planners. The study considers precipitation data from 51 years (1961-2011) at 15 stations.

\section{Methodology}

2.1. Study Area. This study investigates the variability in precipitation time series for a 51-year period (1961-2011) in the Swat River basin, in the Khyber Pakhtunkhwa (KPK) province of Pakistan. The Swat River originates from the high mountains of Swat Kohistan, where the mean elevation is $4500 \mathrm{~m}$ in the northwest parts of the country. The river flows through the Kalam valley and the Swat district, then skirts the Lower Dir district, flows through Malakand and Mardan districts, and outflows into the Kabul River.

The Swat River is important for the future economic development of Pakistan. There are three hydropower plants with a combined operational capacity of $123 \mathrm{MW}$ on the Swat River. At the time of this writing, another hydroelectric power generation plant (Munda Dam), with a projected capacity of $740 \mathrm{MW}$, is being constructed on the Swat River. This dam, along with the hydropower generation, will irrigate 15,100 acres of land. They will also provide flood protection to the Charsadda and Nowshera districts, which were severely affected by flooding in 2010 .

The river's catchment area is generally mountainous, with elevations ranging from approximately $360 \mathrm{~m}$ to $4,500 \mathrm{~m}$ from south to north. Vegetation occurs between $1,800 \mathrm{~m}$ and $3,400 \mathrm{~m}$, and glaciers are visible above $4,000 \mathrm{~m}$. The Swat River basin catchment lies between a latitude of $34^{\circ} 00^{\prime}$ north to $35^{\circ} 56^{\prime}$ north and longitude $70^{\circ} 59^{\prime}$ east to $72^{\circ} 47^{\prime}$ east.

2.2. Data and Methods. The total Swat River basin catchment area is $16750 \mathrm{~km}^{2}$, with 15 meteorological stations shown in Figure 1. The area is further divided into four subregions: upper Swat River basin (A1), Panjkora River basin (A2), Ambahar River basin (A3), and Lower Swat River basin (A4). The catchment areas for these basins are 5968, 5733, 1485 , and $3564 \mathrm{~km}^{2}$, respectively. To detect monotonic trends, monthly precipitation values were added to generate the annual and seasonal precipitation. Mean precipitation values at corresponding stations were considered to determine subbasin precipitation (A1, A2, A3, and A4) and precipitation across the entire Swat River basin (A). This procedure was adopted from Duhan and Pandey [6].

Rain gauge stations within the Swat River catchment area are operated by Pakistan Meteorological Department (PMD), Irrigation Department of KPK province (ID), and Surface Water Hydrology Project (SWHP). Snowy Mountains Engineering Corporation (SMEC), Pakistan, under the Munda Dam construction project, collected the precipitation time series data from these agencies and processed it to ensure homogeneity and quality control [42].

Mann-Kendall and Spearman's rho tests are nonparametric; therefore, data outliers do not affect the results. The homogeneity of the precipitation time series was assessed 


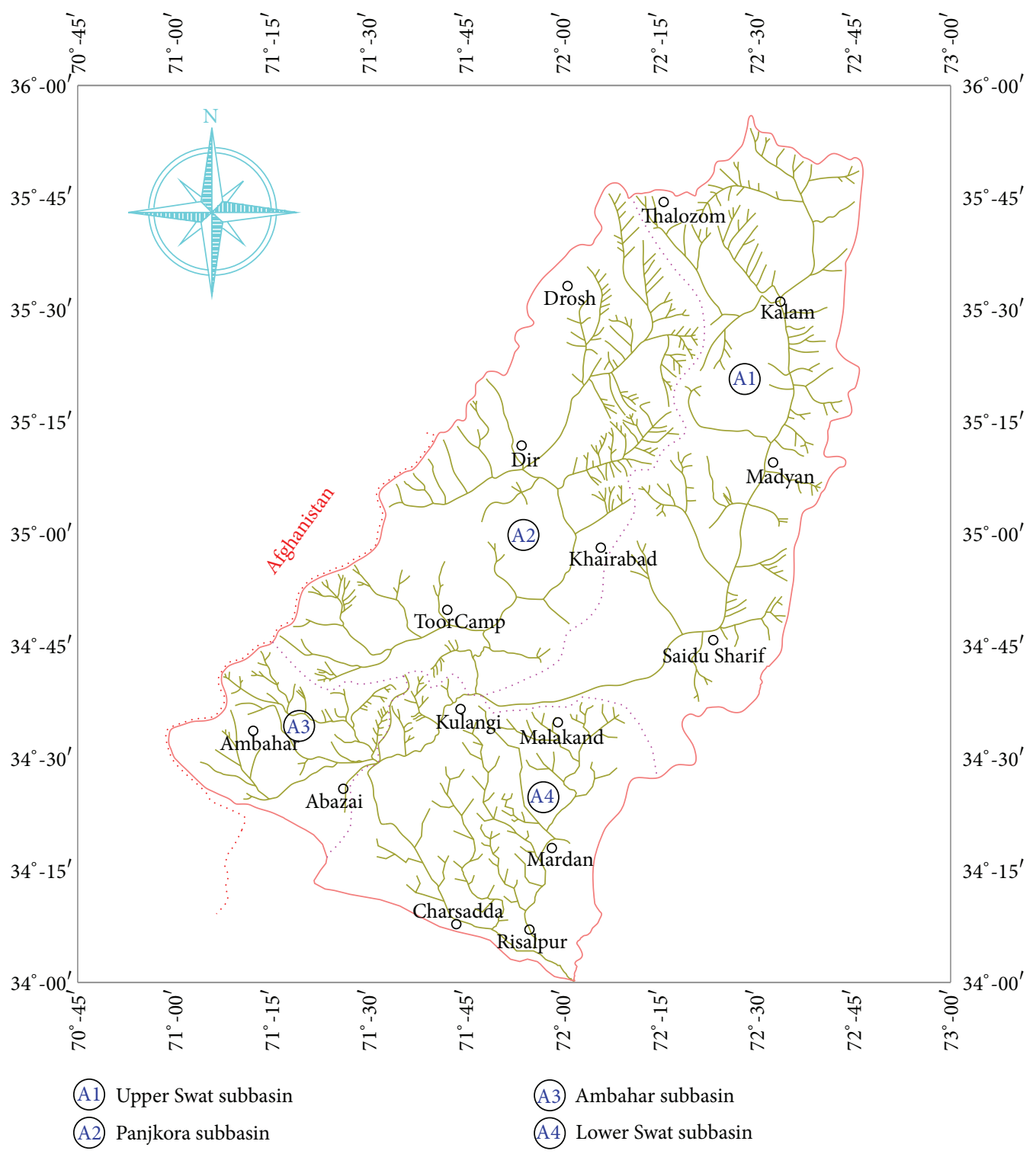

FIGURE 1: Locations of meteorological stations at Swat River basin.

by applying two tests, standard normal homogeneity test (SNHT) $[43,44]$ and Buishand's range (BR) test [45], at a $5 \%$ significance level for each station. The precipitation time series is considered homogenous if the critical values of SNHT and BR statistics are less than 9.17 [46] and 1.27, 1.55 [45], respectively. As Table 1 shows, all the precipitation series were found to be homogenous.

2.3. Statistical Tests. Prior to applying MK and SR tests to identify precipitation trends over the time series from selected stations, data were tested according to the tests' requirements. The trend-free prewhitening (TFPW) approach was applied to eliminate serial correlations in the time series data. The magnitude of the slope in time series data was calculated using Sen's slope method. The statistical methods used are briefly discussed below.
2.3.1. Autocorrelation and TFPW. Removing serial dependence is one of the main problems in testing and interpreting time series data. Applying nonparametric tests to detect trends can significantly affect the results. Therefore, all of the rainfall time series data was first tested for the presence of autocorrelation coefficient $\left(r_{1}\right)$ at a $5 \%$ significance level, using a two-tailed test:

$$
r_{1}=\frac{\sum_{i=1}^{n-1}\left(X_{i}-\bar{X}\right)\left(X_{i+1}-\bar{X}\right)}{\sum_{i=1}^{n}\left(X_{i}-\bar{X}\right)^{2}} .
$$

The autocorrelation coefficient value of $r_{1}$ was tested against the null hypothesis at a $95 \%$ confidence interval, using a twotailed test:

$$
r_{1}(95 \%)=\frac{-1 \pm 1.96 \sqrt{(n-2)}}{n-1} .
$$


TABLE 1: Results of homogeneity tests for mean annual precipitation time series at study stations.

\begin{tabular}{lccc}
\hline \multirow{2}{*}{ Station } & SNHT & \multicolumn{2}{c}{ Buishand's range (BR) test } \\
& $T_{0}$ & $Q / \sqrt{n}$ & 1.08 \\
\hline Thalozom & 9.16 & 1.08 & 1.47 \\
Drosh & 9.06 & 1.17 & 1.08 \\
Kalam & 8.87 & 0.87 & 1.49 \\
Dir & 7.76 & 1.24 & 1.50 \\
Madyan & 4.85 & 1.11 & 0.93 \\
Khairabad & 1.92 & 0.62 & 1.54 \\
ToorCamp & 6.20 & 1.17 & 1.90 \\
Saidu Sharif & 7.42 & 1.18 & 0.86 \\
Malakand & 2.57 & 0.77 & 1.46 \\
Kulangi & 4.28 & 0.97 & 1.39 \\
Ambahar & 5.08 & 1.09 & 1.40 \\
Abazai & 6.86 & 1.21 & 1.24 \\
Mardan & 8.93 & 1.08 & 1.38 \\
Charsadda & 9.02 & 1.25 & 1.25 \\
Risalpur & 7.24 & 0.91 & \\
\hline
\end{tabular}

For homogenous series, $T_{0}<9.17, Q / \sqrt{n}<1.27$, and $R / \sqrt{n}<1.55$.

If $r_{1}$ falls between the upper and lower limits of confidence interval (the data are considered serially correlated), the methods of prewhitening, variance correlation [47], and trend-free prewhitening (TFPW) approach [24] have been proposed. In this study, for the stations where serial correlations were detected in the data, the TFPW approach was applied to remove the correlation for both tests (MannKendall and Spearman's rho). Other researchers [28, 48-51] have also used this approach to eliminate serial correlation in time series data.

2.3.2. The Mann-Kendall Test. The rank-based nonparametric Mann-Kendall $[15,16]$ method was applied to the longterm data in this study to detect statistically significant trends. In this test, the null hypothesis $\left(\mathrm{H}_{0}\right)$ was that there has been no trend in precipitation over time; the alternate hypothesis $\left(\mathrm{H}_{1}\right)$ was that there has been a trend (increasing or decreasing) over time. The mathematical equations for calculating Mann-Kendall Statistics $S, V(S)$ and standardized test statistics $Z$ are as follows:

$$
\begin{gathered}
S=\sum_{i=1}^{n-1} \sum_{j=i+1}^{n} \operatorname{sig}\left(X_{j}-X_{i}\right), \\
\operatorname{sgn}\left(X_{j}-X_{i}\right)= \begin{cases}+1 & \text { if }\left(X_{j}-X_{i}\right)>0 \\
0 & \text { if }\left(X_{j}-X_{i}\right)=0 \\
-1 & \text { if }\left(X_{j}-X_{i}\right)<0, \\
V(S)=\frac{1}{18}\left[n(n-1)(2 n+5)-\sum_{p=1}^{q} t_{p}\left(t_{p}-1\right)\left(2 t_{p}+5\right)\right],\end{cases}
\end{gathered}
$$

$$
Z= \begin{cases}\frac{S-1}{\sqrt{\operatorname{VAR}(S)}} & \text { if } S>0 \\ 0 & \text { if } S=0 \\ \frac{S+1}{\sqrt{\operatorname{VAR}(S)}} & \text { if } S<0 .\end{cases}
$$

In these equations, $X_{i}$ and $X_{j}$ are the time series observations in chronological order, $n$ is the length of time series, $t_{p}$ is the number of ties for $p$ th value, and $q$ is the number of tied values. Positive $Z$ values indicate an upward trend in the hydrologic time series; negative $Z$ values indicate a negative trend. If $|Z|>Z_{1-\alpha / 2},\left(\mathrm{H}_{0}\right)$ is rejected and a statistically significant trend exists in the hydrologic time series. The critical value of $Z_{1-\alpha / 2}$ for a $p$ value of 0.05 from the standard normal table is 1.96 .

2.3.3. Spearman's rho Test. Spearman's rho $[17,18]$ test is another rank-based nonparametric method used for trend analysis and was applied as a comparison with the MannKendall test. In this test, which assumes that time series data are independent and identically distributed, the null hypothesis $\left(\mathrm{H}_{0}\right)$ again indicates no trend over time; the alternate hypothesis $\left(\mathrm{H}_{1}\right)$ is that a trend exists and that data increase or decrease with $i$ [24]. The test statistics $R_{\mathrm{sp}}$ and standardized statistics $Z_{\mathrm{sp}}$ are defined as

$$
\begin{gathered}
R_{\mathrm{sp}}=1-\frac{6 \sum_{i=1}^{n}\left(D_{i}-i\right)^{2}}{n\left(n^{2}-1\right)}, \\
Z_{\mathrm{sp}}=R_{\mathrm{sp}} \sqrt{\frac{n-2}{1-R_{\mathrm{sp}}^{2}}} .
\end{gathered}
$$

In these equations, $D_{i}$ is the rank of $i$ th observation, $I$ is the chronological order number, $n$ is the total length of the time series data, and $Z_{\mathrm{sp}}$ is Student's $t$-distribution with $(n-2)$ degree of freedom. The positive values of $Z_{\text {sp }}$ represent an increasing trend across the hydrologic time series; negative values represent the decreasing trends. The critical value of $t$ at a 0.05 significance level of Student's $t$-distribution table is defined as $t_{(n-2,1-\alpha / 2)}$ [12]. If $\left|Z_{\text {sp }}\right|>t_{(n-2,1-\alpha / 2)},\left(\mathrm{H}_{0}\right)$ is rejected and a significant trend exists in the hydrologic time series.

2.3.4. Sen's Slope Estimator. Sen's nonparametric method [52] was used to estimate the magnitude of trends in the time series data:

$$
T_{i}=\frac{x_{j}-x_{k}}{j-k} .
$$

In this equation, $x_{j}$ and $x_{k}$ represent data values at time $j$ and $k$, respectively. Consider

$$
Q_{i}= \begin{cases}T_{(N+1) / 2} & N \text { is odd } \\ \frac{1}{2}\left(T_{N / 2}+T_{(N+2) / 2}\right) & N \text { is even. }\end{cases}
$$

A positive $Q_{i}$ value represents an increasing trend; a negative $Q_{i}$ value represents a decreasing trend over time. 
TABLE 2: Summary of geographic conditions and mean annual precipitation statistics for study stations.

\begin{tabular}{|c|c|c|c|c|c|c|c|c|}
\hline Station & Longitude & Latitude & Elevation $(\mathrm{m})$ & Mean $(\mathrm{mm})$ & STD & $C_{s}$ & $C_{k}$ & $C_{v}$ \\
\hline Thalozom & $72^{\circ}-15^{\prime}$ & $35^{\circ}-44^{\prime}$ & 4200 & 751.1 & 209.9 & -0.266 & 0.082 & 0.291 \\
\hline Drosh & $72^{\circ}-00^{\prime}$ & $35^{\circ}-33^{\prime}$ & 1465 & 463.5 & 153.7 & 1.167 & 2.441 & 0.332 \\
\hline Kalam & $72^{\circ}-33^{\prime}$ & $35^{\circ}-31^{\prime}$ & 2000 & 934.5 & 317.0 & -0.599 & 0.323 & 0.353 \\
\hline Dir & $71^{\circ}-53^{\prime}$ & $35^{\circ}-12^{\prime}$ & 1321 & 548.2 & 152.1 & -0.545 & 0.919 & 0.285 \\
\hline Madyan & $72^{\circ}-32^{\prime}$ & $35^{\circ}-09^{\prime}$ & 1320 & 962.3 & 287.8 & 0.240 & 1.300 & 0.307 \\
\hline Khairabad & $72^{\circ}-06^{\prime}$ & $34^{\circ}-58^{\prime}$ & 894 & 703.7 & 152.2 & 1.410 & 4.281 & 0.216 \\
\hline ToorCamp & $71^{\circ}-42^{\prime}$ & $34^{\circ}-50^{\prime}$ & 854 & 544.0 & 159.2 & -0.436 & 0.841 & 0.299 \\
\hline Saidu Sharif & $72^{\circ}-25^{\prime}$ & $34^{\circ}-45^{\prime}$ & 961 & 990.1 & 389.8 & 1.842 & 6.463 & 0.398 \\
\hline Malakand & $71^{\circ}-46^{\prime}$ & $34^{\circ}-38^{\prime}$ & 603 & 609.8 & 252.6 & 2.474 & 11.668 & 0.424 \\
\hline Kulangi & $71^{\circ}-59^{\prime}$ & $34^{\circ}-35^{\prime}$ & 688 & 625.4 & 192.5 & 0.037 & -0.170 & 0.308 \\
\hline Ambahar & $71^{\circ}-12^{\prime}$ & $34^{\circ}-33^{\prime}$ & 694 & 455.0 & 148.5 & -0.004 & 0.764 & 0.333 \\
\hline Abazai & $71^{\circ}-33^{\prime}$ & $34^{\circ}-26^{\prime}$ & 320 & 500.7 & 152.7 & -0.093 & 0.963 & 0.312 \\
\hline Mardan & $71^{\circ}-58^{\prime}$ & $34^{\circ}-18^{\prime}$ & 283 & 657.4 & 297.4 & 0.735 & 1.392 & 0.452 \\
\hline Charsadda & $71^{\circ}-43^{\prime}$ & $34^{\circ}-07^{\prime}$ & 276 & 591.6 & 207.4 & 0.973 & 1.031 & 0.350 \\
\hline Risalpur & $71^{\circ}-54^{\prime}$ & $34^{\circ}-06^{\prime}$ & 309 & 611.8 & 176.8 & 0.312 & -0.098 & 0.289 \\
\hline
\end{tabular}

\section{Results and Discussion}

3.1. Preliminary Analysis. The preliminary analysis for this study included computing the mean, standard deviation, coefficient of skewness, coefficient of kurtosis, and coefficient of variation in the annual precipitation time series for each station. Table 2 presents these statistical parameters for the 51-year time period studied (1961-2011). The mean annual precipitation varied between $455 \mathrm{~mm}$ in the southwest part of the Swat River basin catchment area (Ambahar) and $990.1 \mathrm{~mm}$ in the southeast part (Saidu Sharif). As the table shows, the coefficient of skewness varied from -0.266 to 2.474; kurtosis varied between -0.170 and 11.668. For time series data to be considered normally distributed, the coefficient of skewness and kurtosis must be equal to 0 and 3, respectively. Table 2 indicates, therefore, that the data are positively skewed and not normally distributed. The coefficient of variation, the measure of dispersion around the mean, was also calculated to analyze the spatial variability of annual precipitation for each station. This coefficient varied between $21.6 \%$ (Khairabad) and 45.2\% (Mardan). The average variation of the precipitation over the complete river basin was $28.9 \%$.

3.2. Long-Term Pattern on Seasonal and Annual Scale. Longterm climatic patterns were assessed using standardized seasonal and annual precipitation time series data. To reduce local fluctuations, LOWESS [53-55] curves were fitted over time based on seasonal and annual precipitation time series data. The LOWESS curve for winter precipitation (Figure 2(a)) showed a decreasing trend in the first decade. In the second decade, the trend was constant. The minimum LOWESS curve value was observed in 1990; values then gradually rose through 2010. Overall, the curve based on winter season data suggested a decline in precipitation. After 1990, there was a gradual rise, though small local fluctuations were ignored. The LOWESS curve for spring precipitation (Figure 2(b)) showed a gradual increase in the first three decades. After attaining its highest value in 1990, the value declined over the last two decades.

The LOWESS curve for summer precipitation showed a constant trend in the first decade and then started to decline up to 1978 (Figure 2(c)). For 1978-1992, the curve started to gradually increase through the remaining years. The LOWESS curve for autumn precipitation exhibited a decreasing trend through 1982; for the remaining time periods, there was an increase in precipitation. For the annual precipitation time series, the LOWESS curve showed slight variations in every decade, but the overall trend was nearly constant throughout the time series. Figure 2 shows the precipitation patterns; LOWESS curves are used to show patterns and do not explain statistically significant trends in the time series.

3.3. Monthly Analysis. The Mann-Kendall (MK) and Spearman's (SR) rho tests were applied on a monthly scale to detect trends in the precipitation series at different stations. Table 3 shows the results and illustrates that the results of both tests were similar to one another. Monthly trend tests showed a mix of positive and negative trends at different stations. At Thalozom, statistically significant negative and positive trends were found in April and June, respectively. Significant positive trends were detected at Dir and Drosh stations in March and August; no significant trends were found for other months. The Saidu Sharif station exhibited significant positive trends from January to June and from October to December but had negative trends in July and August. Significant positive trends were found at most of the stations in the months of May and June; significant negative trends were seen in July and August. In other stations, a mix of significantly positive and negative trends occurred for a few months of the year. Figure 3 shows the spatial variation in the precipitation time series for each month in the Swat River basin from 1961 to 2011.

The magnitude of statistically significant trends on a monthly scale was determined using Sen's slope estimator. 


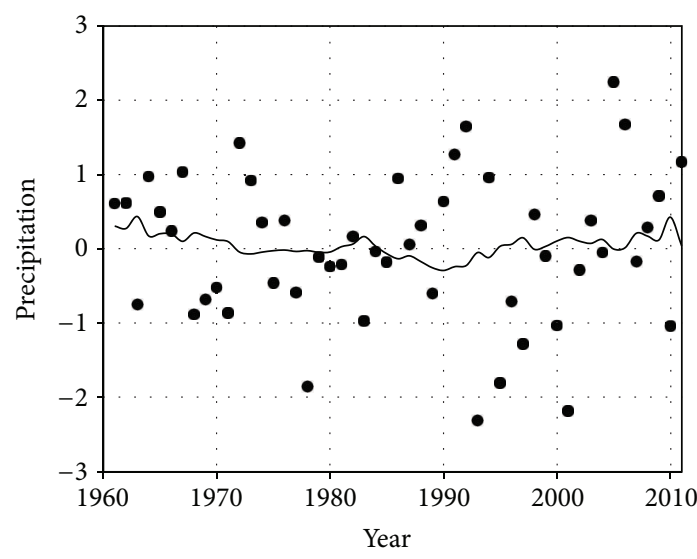

- Original data — LOWESS line

(a)

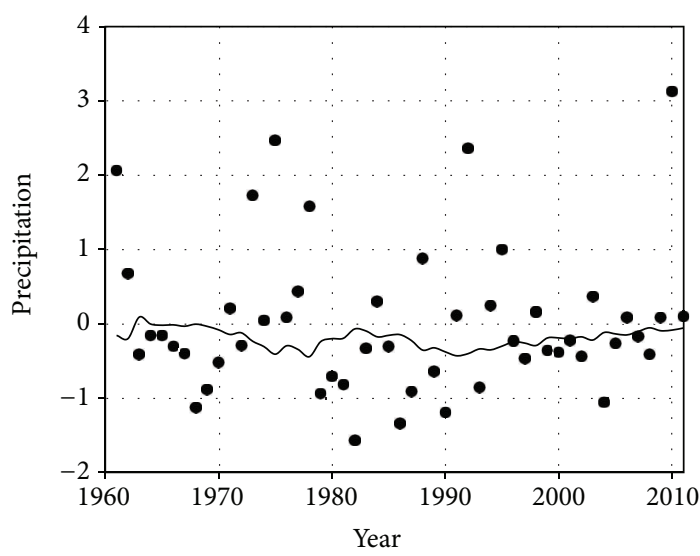

- Original data _ LOWESS line

(c)

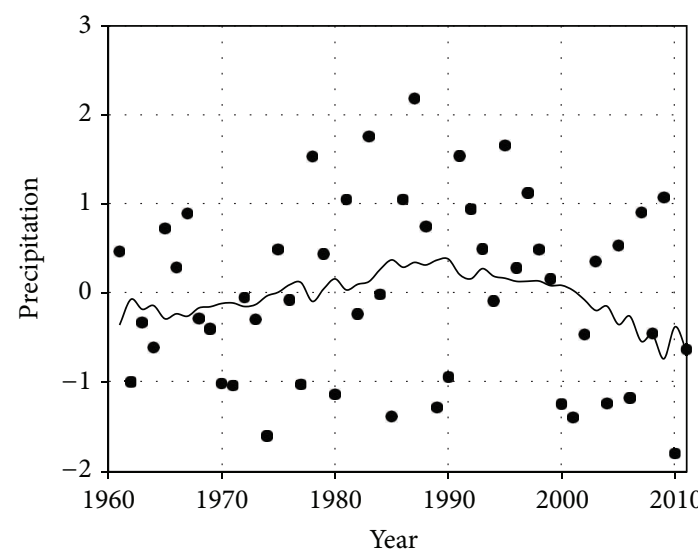

- Original data

- LOWESS line

(b)

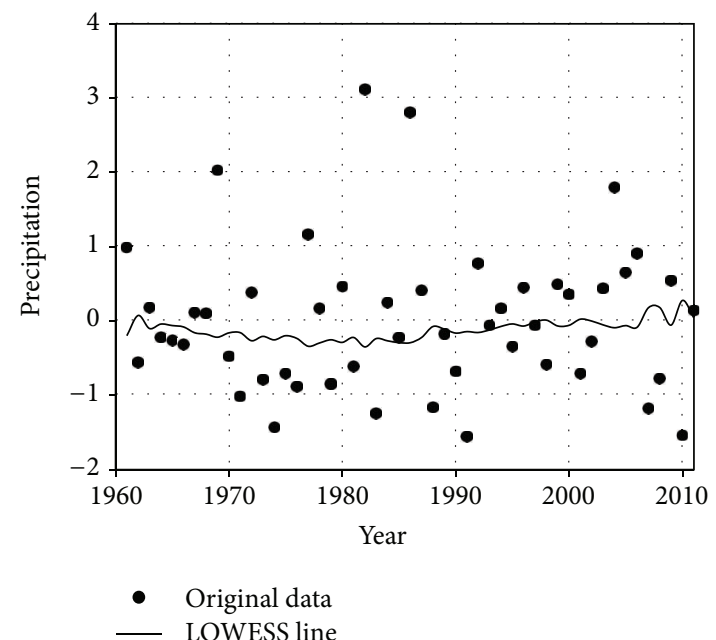

(d)

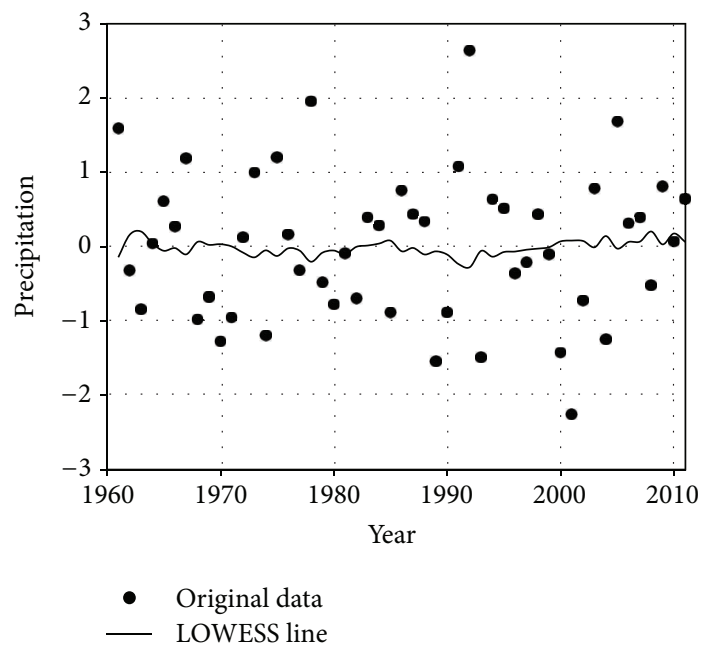

(e)

FIGURE 2: Standardized precipitation and LOWESS trend curves at Swat River basin: (a) winter, (b) spring, (c) summer, (d) autumn, and (e) annual. 
|

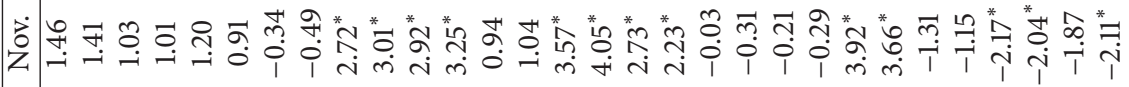

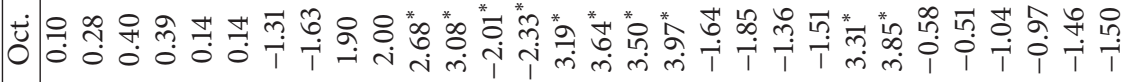

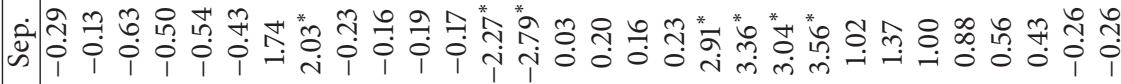

op

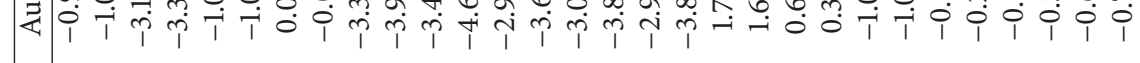

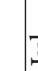

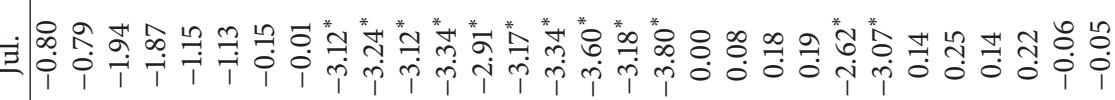

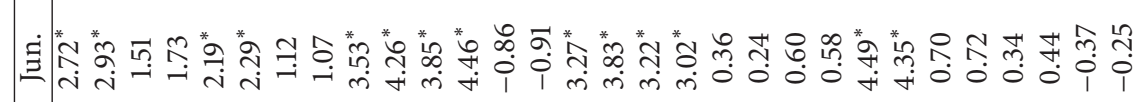

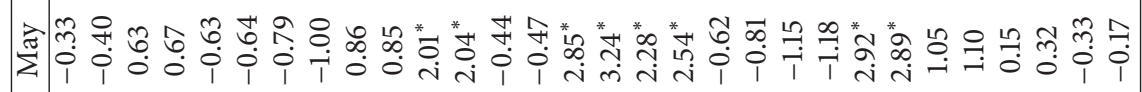

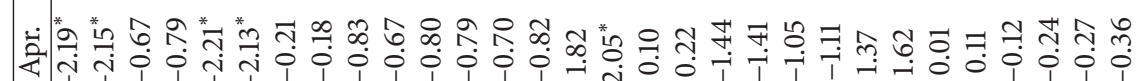
हี $\stackrel{y}{\Sigma}$ $\ddot{n}$

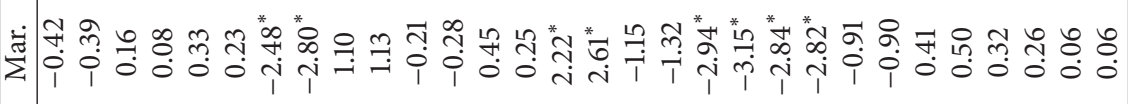

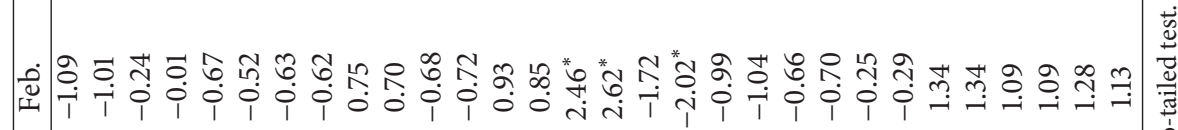

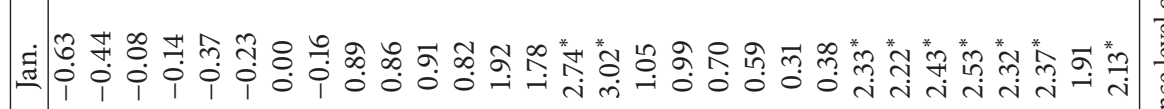

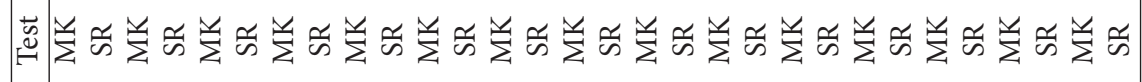

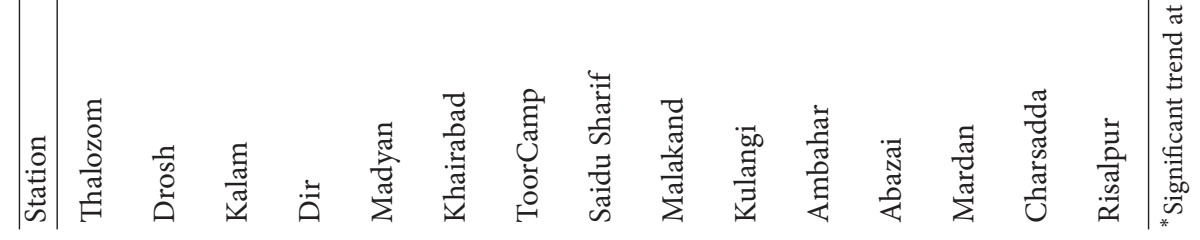



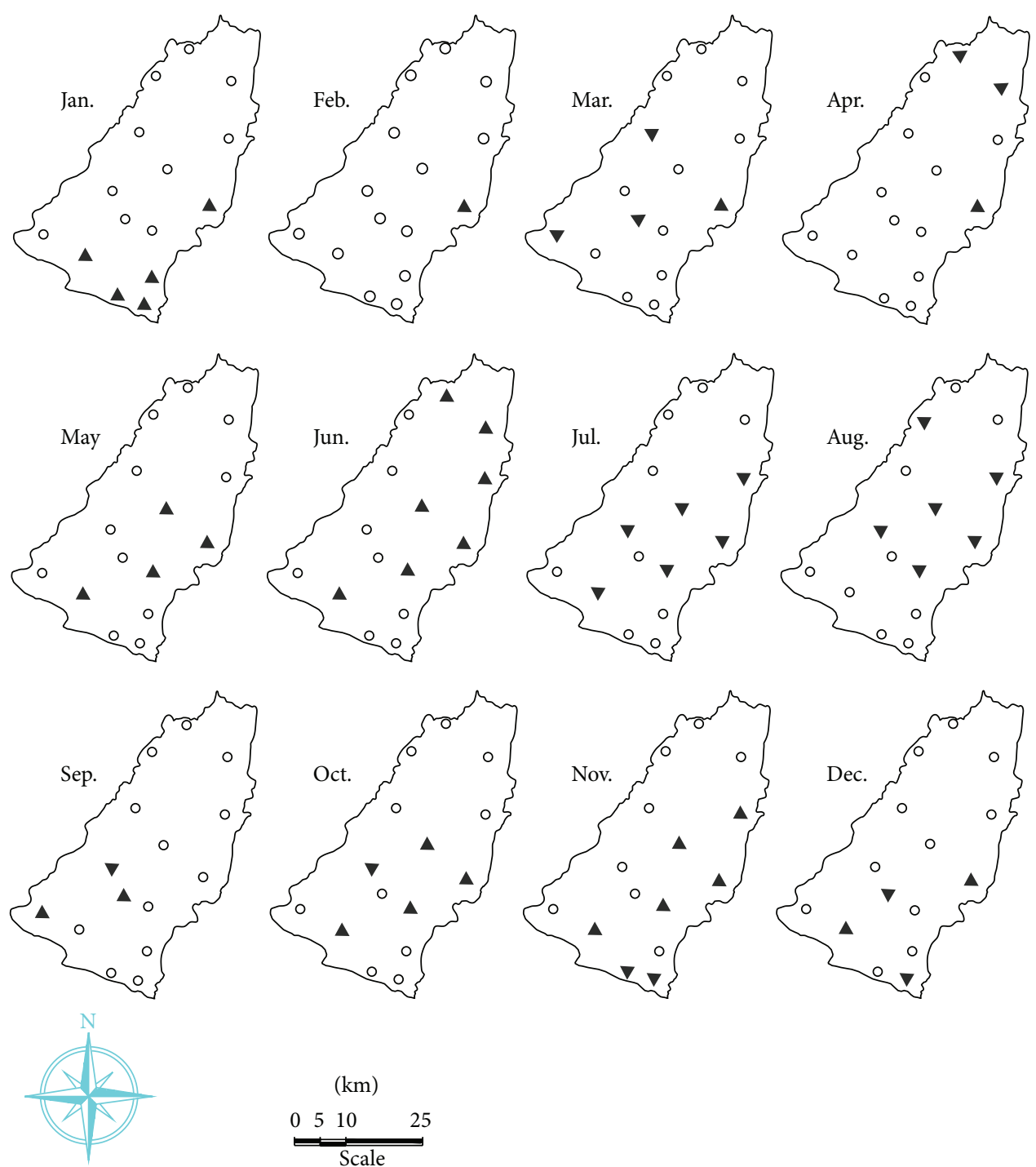

Significant increasing trend Significant decreasing trend

No trend

FIGURE 3: Location of sites with increasing, decreasing, and no trends at $5 \%$ significance level for the monthly precipitation time series.

The results show that trends at Saidu Sharif, Madyan, and Kalam were more rapid (e.g., sharper increases and decreases) compared to other stations. The Saidu Sharif station had the maximum negative decline in monthly precipitation $(1.83 \mathrm{~mm} / \mathrm{month})$ as well as the maximum positive increase $(1.43 \mathrm{~mm} / \mathrm{month})$ during the months of July and March, respectively. Figure 4 shows the trends in maximum monthly precipitation variation at the Saidu Sharif station.

3.4. Seasonal and Annual Analysis. The MK and SR tests were also used to identify trends in seasonal and annual precipitation between 1961 and 2011; Table 4 shows the results. Similar to the monthly analysis, results from both statistical tests, MK and SR, were consistent with one another. A mix of negative and positive trends was seen at different stations. Thalozom, Kalam, and Dir stations, which had shown trends with the monthly time scale, did not exhibit statistically significant trends for the seasonal and annual precipitation time series. At Madyan, Khairabad, and Malakand stations, there were significant negative trends in the summer and positive trends in the autumn. Significant negative trends were observed in the spring season only at ToorCamp, Kulangi, and Ambahar stations. For the annual precipitation series, significant positive trends were detected only at Saidu Sharif, Mardan, and Charsadda stations. At other stations, significant positive trends were seen for winter and autumn seasons and for the annual precipitation series; however, negative trends were detected in spring and summer seasons. Figure 5 presents the spatial distribution of seasonal and annual precipitation trends.

The Saidu Sharif station showed the maximum positive trend in annual precipitation series $(7.48 \mathrm{~mm} /$ year) across 


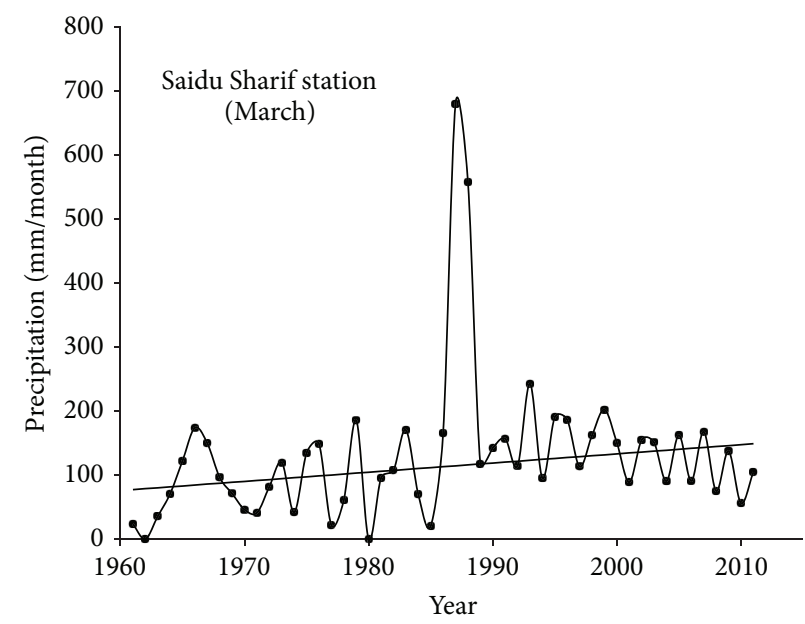

(a)

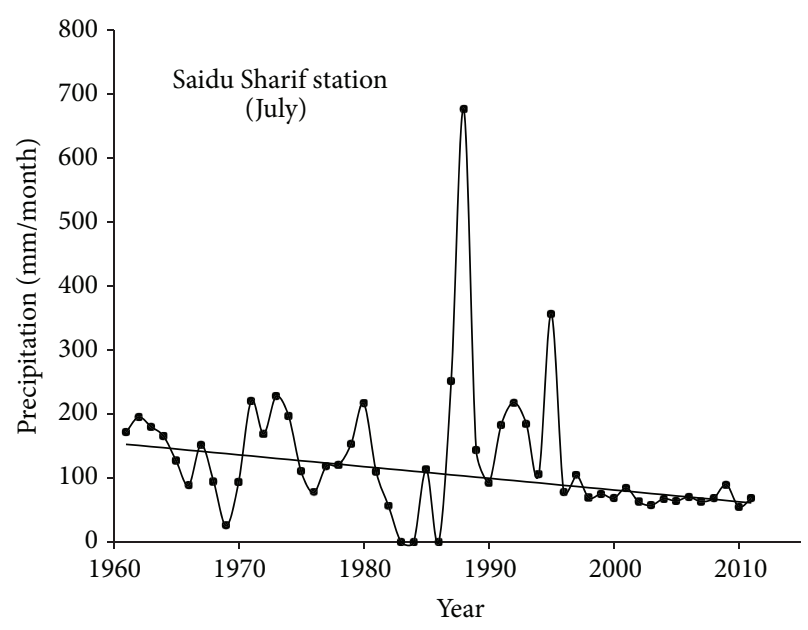

(b)

FIGURE 4: Variations of monthly precipitation time series in stations with most significant trends during 1961-2011.

TABLE 4: MK and SR tests results for precipitation in seasonal and annual time series.

\begin{tabular}{|c|c|c|c|c|c|c|}
\hline Station & Test & Winter & Spring & Summer & Autumn & Annual \\
\hline \multirow{2}{*}{ Thalozom } & MK & -1.20 & -1.62 & -1.20 & 1.48 & -1.49 \\
\hline & SR & -1.14 & -1.52 & -1.10 & 1.35 & -1.45 \\
\hline \multirow{2}{*}{ Drosh } & MK & 0.42 & -0.78 & -1.96 & 0.97 & -0.44 \\
\hline & SR & 0.49 & -0.74 & $-2.09^{*}$ & 1.27 & -0.48 \\
\hline \multirow{2}{*}{ Kalam } & MK & -0.62 & -1.39 & -1.71 & 1.60 & -1.10 \\
\hline & $\mathrm{SR}$ & -0.37 & -1.21 & -1.58 & 1.57 & -0.87 \\
\hline \multirow{2}{*}{ Dir } & MK & -0.28 & -1.48 & -0.47 & -0.76 & -1.38 \\
\hline & $\mathrm{SR}$ & -0.62 & -1.50 & -0.58 & -0.97 & -1.46 \\
\hline \multirow{2}{*}{ Madyan } & MK & 1.20 & 0.03 & $-2.58^{*}$ & $3.65^{*}$ & 0.42 \\
\hline & SR & 1.37 & 0.33 & $-2.44^{*}$ & $4.21^{*}$ & 0.78 \\
\hline \multirow{2}{*}{ Khairabad } & MK & 0.26 & -0.65 & $-3.02^{*}$ & $3.25^{*}$ & -0.73 \\
\hline & SR & 0.21 & -0.76 & $-3.53^{*}$ & $3.64^{*}$ & -0.72 \\
\hline \multirow{2}{*}{ ToorCamp } & MK & -0.63 & $-2.03^{*}$ & 0.24 & -0.73 & -0.44 \\
\hline & SR & -0.96 & $-2.17^{*}$ & 0.23 & -0.92 & -1.59 \\
\hline \multirow{2}{*}{ Saidu Sharif } & MK & $3.46^{*}$ & $2.39^{*}$ & -1.56 & 0.69 & $3.28^{*}$ \\
\hline & SR & $4.04^{*}$ & $2.80^{*}$ & -1.56 & 1.48 & $2.78^{*}$ \\
\hline \multirow{2}{*}{ Malakand } & MK & -0.70 & -1.10 & $-2.70^{*}$ & $3.37^{*}$ & -1.19 \\
\hline & $\mathrm{SR}$ & -0.68 & -1.15 & $-3.19^{*}$ & $3.73^{*}$ & -1.40 \\
\hline \multirow{2}{*}{ Kulangi } & MK & -1.22 & $-2.61^{*}$ & 0.31 & -0.99 & -1.44 \\
\hline & SR & -1.56 & $-2.84^{*}$ & 0.37 & -1.27 & -1.72 \\
\hline \multirow{2}{*}{ Ambahar } & MK & -0.66 & $-2.06^{*}$ & -0.63 & -0.99 & -1.57 \\
\hline & SR & -0.76 & $-2.24^{*}$ & -0.58 & -1.10 & -1.41 \\
\hline \multirow{2}{*}{ Abazai } & MK & 1.79 & -0.15 & -0.99 & $4.29^{*}$ & 0.96 \\
\hline & $\mathrm{SR}$ & $2.17^{*}$ & 0.07 & -0.72 & $6.04^{*}$ & 1.22 \\
\hline \multirow{2}{*}{ Mardan } & MK & $2.81^{*}$ & 1.45 & 0.95 & -1.02 & $2.59^{*}$ \\
\hline & SR & $3.10^{*}$ & 1.34 & 0.98 & -0.85 & $2.80^{*}$ \\
\hline \multirow{2}{*}{ Charsadda } & MK & $2.66^{*}$ & 0.97 & 0.73 & -1.94 & $2.14^{*}$ \\
\hline & SR & $2.93^{*}$ & 0.88 & 0.60 & -1.76 & $2.17^{*}$ \\
\hline \multirow{2}{*}{ Risalpur } & MK & $2.43^{*}$ & 0.44 & -0.06 & -1.54 & 1.98 \\
\hline & SR & $2.54^{*}$ & 0.40 & -0.05 & -1.90 & 1.95 \\
\hline
\end{tabular}

\footnotetext{
* Significant trend at $5 \%$ significance level of two-tailed test.
} 


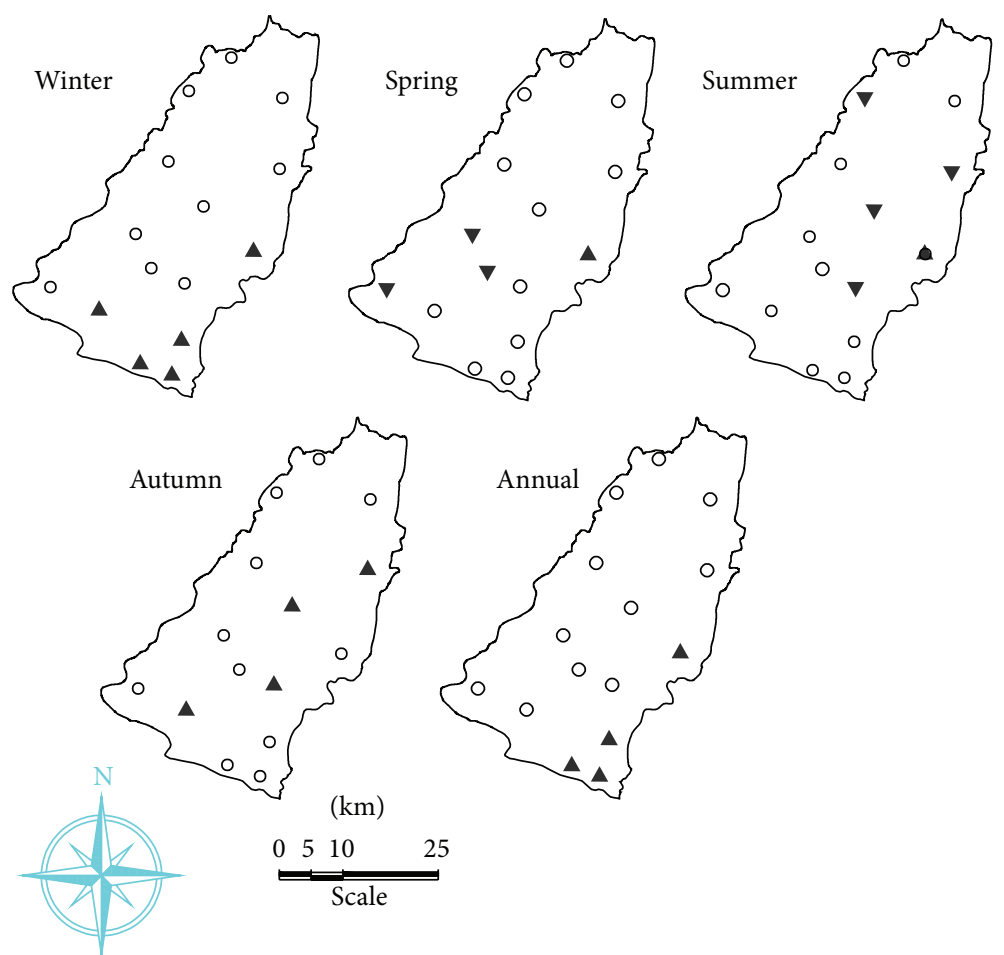

Significant increasing trend

Significant decreasing trend

No trend

FIGURE 5: Location of sites with increasing, decreasing, and no trends at 5\% significance level for the seasonal and annual precipitation time series.

study stations from 1961 to 2011; the Thalozom station showed a negative trend, with a decreasing rate of $3.70 \mathrm{~mm} /$ year. Figure 6 displays the results of the magnitude of variation in the annual precipitation for the Saidu Sharif, Mardan, Charsadda, and Thalozom stations.

3.5. Trend Analysis over Entire River Basin. The effect of climate change on precipitation was also analyzed for the entire Swat River basin by applying the MK and SR tests on monthly, seasonal, and annual scale. As Figure 1 showed, the entire Swat River catchment (A) is divided into four subbasins: upper subbasin (A1), Panjkora subbasin (A2), Ambahar subbasin (A3), and Lower subbasin (A4). Table 5 presents trends in monthly precipitation across the subbasins and for the full basin. The table shows significant positive trends in the months of June and November for the upper subbasin (A1) and the entire Swat River basin (A); negative trends were seen in these locations in July and August. In the Panjkora subbasin (A2), statistically significant positive trends were identified over time in June; a negative trend was seen from July to September. The maximum number of significant cases (8) was observed in data from the Ambahar subbasin (A3). The Lower subbasin (A4) showed a significant positive trend only during January; no significant trends in other months were identified. As a simpler summary, significant negative trends in precipitation over time were seen from July to September; positive trends over time were seen in January, May, June, and October to December in different Swat River subbasins.

To detect precipitation trends in each subbasin and entire Swat River basin, the MK and SR tests were again applied to seasonal and annual precipitation data for the 51-year study period (1961-2011). As Table 6 shows, both test methods showed similar results. The upper subbasin (A1) experienced statistically significant negative trends in the summer and positive trends in the autumn. The Panjkora subbasin (A2) and Lower subbasin (A4) showed significant negative trends in the summer and positive trends in the winter. Significant positive trends were found across the subbasins in winter and autumn seasons; however, there was a negative trend in summer at Ambahar subbasin (A3) and across the entire Swat River basin (A). For the annual and spring precipitation time series, there were no statistically significant trends. Significant positive trends were seen in winter and autumn; in summer, negative trends were seen across different subbasins and the full Swat River basin.

The Lower subbasin exhibited the maximum positive trend over time $(2.18 \mathrm{~mm} /$ year $)$ in the weighted annual precipitation time series; the Panjkora subbasin showed a negative trend with a decreasing rate of participation at $0.90 \mathrm{~mm} /$ year. The entire Swat River basin showed a positive trend in precipitation ( $0.48 \mathrm{~mm} /$ year $)$, as shown in Table 6. 


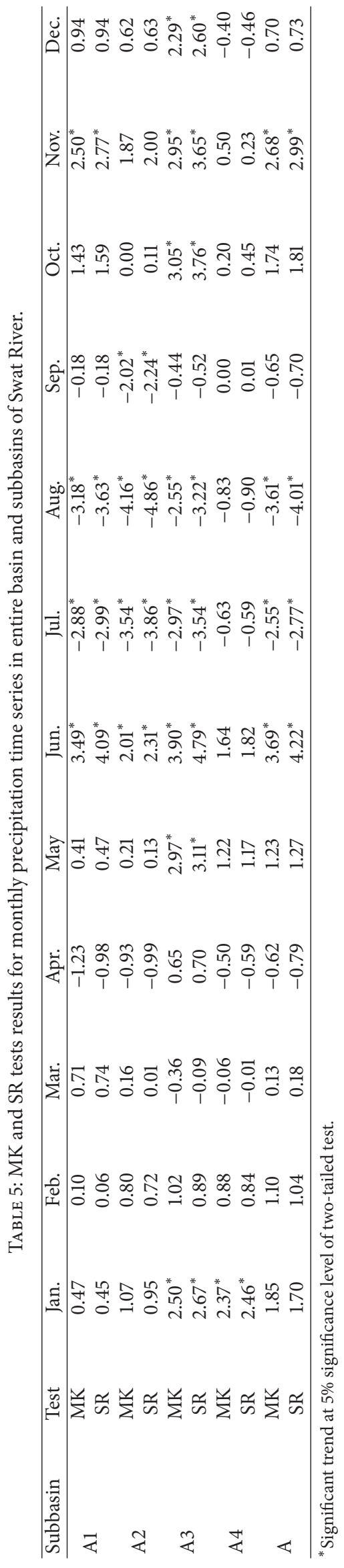




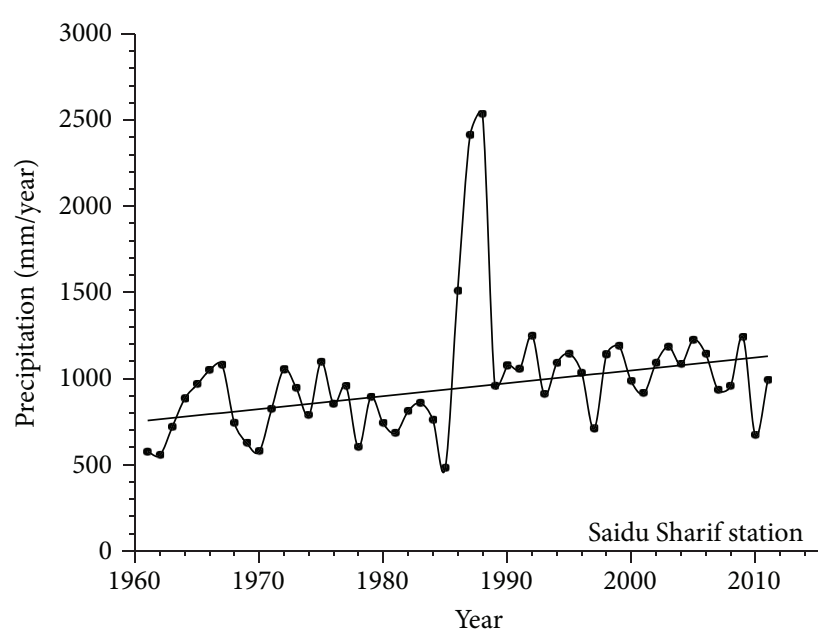

(a)

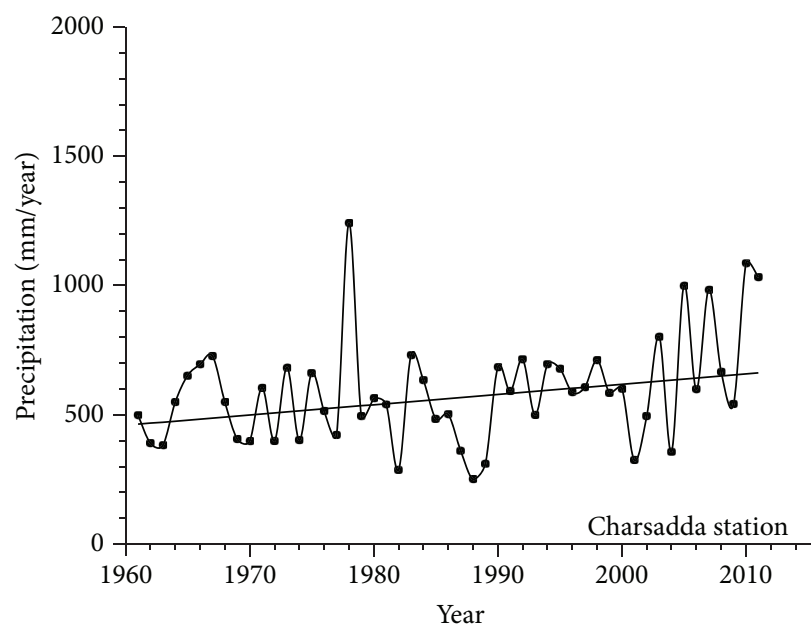

(c)

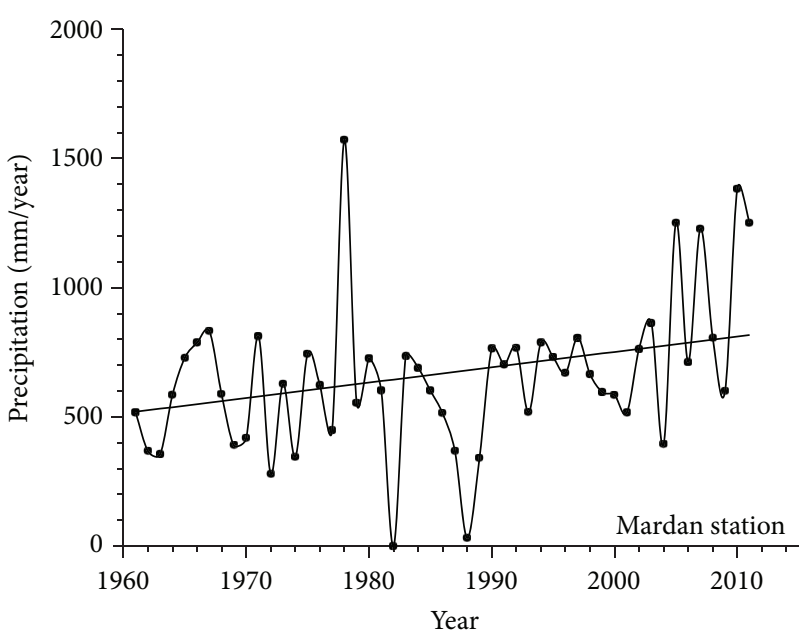

(b)

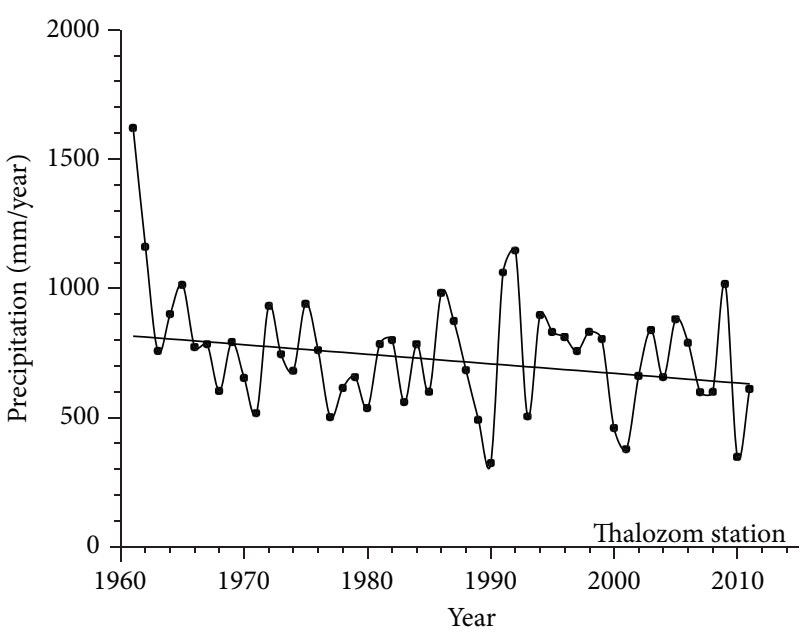

(d)

FIGURE 6: Variations of annual precipitation time series in stations with significant trends during 1961-2011.

3.6. Comparison of Results. Results from both statistical tests, MK and SR, were consistent with each other. The percentages of statistically significant cases to total tested cases for the MK and SR tests were 32\% and 30\%, respectively, showing agreement across methods. This consistency in statistical performance was also found in other studies [24, 28].

\section{Discussion}

This study investigated variability in monthly, seasonal, and annual precipitation at 15 stations in the Swat River basin over a 51-year study period (1961-2011). Precipitation trends were also analyzed for each subbasin and entire Swat River basin. The mean annual precipitation at different stations showed considerable variation, with a standard deviation of $176.8 \mathrm{~mm}$ from the mean annual rainfall of $694 \mathrm{~mm}$. The Saidu Sharif, Mardan, and Charsadda stations showed significant positive trends (increased precipitation over time) at $5 \%$ significance level in the annual precipitation series.
The maximum number of significant changes in monthly precipitation over time was detected at Saidu Sharif, Abazai, and Khairabad stations. Saidu Sharif station showed the maximum increasing slope (indicating sharpest change over time) of $7.48 \mathrm{~mm} /$ year among the selected stations in the Swat River basin.

These study results follow the same statistical trends reported by Hartmann and Andresky [35] for northwest parts of Pakistan. Findings were consistent with results from Dimri [56], Ghaffar and Javid [57], and Rasul [58], wherein they found statistically significant increasing trends in winter precipitation for northwest areas of Pakistan. The results of this analysis also support finding of Hanif et al. [37] wherein they found significant variations in summer season precipitation. These variations in precipitation trends may lead Pakistan towards more water related disasters such as droughts and floods in the near future. Basistha et al. [59] proposed possible causes of the changing precipitation trends, such as global climate shifts [60], dwindling global 
TABLE 6: MK and SR results for seasonal and annual precipitation time series in entire basin and subbasin of Swat River.

\begin{tabular}{lccccccc}
\hline Subbasin & Change $(\mathrm{mm} /$ year $)$ & Test & Winter & Spring & Summer & Autumn & Annual \\
\hline \multirow{2}{*}{ A1 } & \multirow{2}{*}{0.73} & MK & 0.55 & -0.24 & $-2.42^{*}$ & $3.05^{*}$ & -0.34 \\
& & SR & 0.57 & 0.01 & $-2.27^{*}$ & $3.47^{*}$ & 1.18 \\
A2 & \multirow{2}{*}{0.90} & MK & 1.28 & -0.23 & $-3.85^{*}$ & 1.58 & -0.81 \\
& & SR & 1.18 & -0.35 & $-4.44^{*}$ & 1.64 \\
A3 & \multirow{2}{*}{0.30} & MK & $2.66^{*}$ & 0.16 & $-2.65^{*}$ & $3.75^{*}$ & 0.90 \\
& \multirow{2}{*}{2.18} & SR & $2.95^{*}$ & 0.27 & $-3.09^{*}$ & $4.60^{*}$ & 0.40 \\
A4 & MK & $2.42^{*}$ & 0.60 & -0.21 & 0.24 & 1.66 \\
& \multirow{2}{*}{0.48} & SR & $2.72^{*}$ & 0.54 & -0.37 & 0.43 & 1.73 \\
A & MK & $2.14^{*}$ & -0.11 & $-2.97^{*}$ & $3.07^{*}$ & 0.42 \\
& & SR & $2.25^{*}$ & -0.14 & $-3.40^{*}$ & $3.36^{*}$ & 0.38 \\
\hline
\end{tabular}

${ }^{*}$ Significant trend at 5\% significance level of two-tailed test.

monsoon circulation [61], decline in forest cover [62,63], land use changes and practices (e.g., irrigated agriculture) [64, 65], and increasing aerosols from anthropogenic activities [66].

\section{Conclusions}

This paper analyzed trends in monthly, seasonal, and annual precipitation in the Swat River basin over the 51-year study period (1961-2011). A mix of positive and negative trends was observed at various stations and subbasins. The months of June, November, July, and August showed the maximum number of significant cases at various stations in monthly precipitation. The trends were positive in May and June and were negative in July and August. This indicates a shift in precipitation series on monthly scale. Significant positive trends were detected in winter and autumn and annually; negative trends were seen in spring and summer seasons. Saidu Sharif, Mardan, and Charsadda stations exhibited significant positive trends in annual precipitation at a $95 \%$ confidence level; the remaining stations did not experience a statistically significant trend.

For the entire Swat River basin, no significant trends were detected in any subbasin for the annual precipitation series. Seasonally, winter and autumn experienced significant positive trends, and summer experienced negative trends in different subbasins in the Swat River basin. Most statistically significant trend cases under different scenarios were positive (61\%). The results obtained with the Mann-Kendall (MK) and Spearman's rho tests showed agreement in their assessments of monthly, seasonal, and annual precipitation trends. The variability of negative and positive trends at various stations points to the need for more detailed studies on the climate change of this region.

\section{Conflict of Interests}

The authors declare that there is no conflict of interests regarding the publication of this paper.

\section{Acknowledgments}

The authors thank Pakistan Meteorological Department (PMD), Water and Power Development Authority
(WAPDA), Pakistan, and Snowy Mountains Engineering Corporation (SMEC) for providing cost-free data for this study.

\section{References}

[1] M. D. Rahman and M. Begum, "Application of non parametric test for trend detection of rainfall in the largest Island of Bangladesh," ARPN Journal of Earth Sciences, vol. 2, no. 2, pp. 40-44, 2013.

[2] IPCC, The Physical Science Basis. Contribution of Working Group I to the Fourth Assessment Report of the Intergovernmental Panel on Climate Change, Cambridge University Press, Cambridge, UK, 2007.

[3] A. B. Farooq and A. H. Khan, "Climate change perspective in Pakistan," in Proceedings of the Capacity Building APN Workshop on Global Change Research, pp. 39-46, Islamabad, Pakistan, 2004.

[4] Z. Z. Hu, S. Yang, and R. Wu, "Long-term climate variations in China and global warming signals," Journal of Geophysical Research, vol. 108, no. D19, 2003.

[5] P. Zhai and X. Pan, "Trends in temperature extremes during 1951-1999 in China," Geophysical Research Letters, vol. 30, no. 17, p. 1913, 2003.

[6] D. Duhan and A. Pandey, "Statistical analysis of long term spatial and temporal trends of precipitation during 1901-2002 at Madhya Pradesh, India," Atmospheric Research, vol. 122, pp. 136-149, 2013.

[7] B. J. Peterson, R. M. Holmes, J. W. McClelland et al., "Increasing river discharge to the Arctic ocean," Science, vol. 298, no. 5601, pp. 2171-2173, 2002.

[8] N. I. Savelieva, I. P. Semiletov, L. N. Vasilevskaya, and S. P. Pugach, "A climate shift in seasonal values of meteorological and hydrological parameters for Northeastern Asia," Progress in Oceanography, vol. 47, no. 2-4, pp. 279-297, 2000.

[9] Y. F. Shi, Y. P. Shen, and R. J. Hu, "Preliminary study on signal, impact and foreground of climatic shift from warm-dry to warm-humid in Northwest China," Journal of Glaciology and Geocryology, vol. 24, pp. 219-226, 2002 (Chinese).

[10] S. Farhana and M. M. Rahman, "Characterizing rainfall trend in Bangladesh by temporal statistics analysis," in Proceedings of the 4th Annual Paper Meet and 1st Civil Engineering Congress, Dhaka, Bangladesh, 2011.

[11] R. H. Rimi, S. H. Rahman, S. Karmakar, and S. G. Hussain, "Trend analysis of climate change and investigation on its 
probable impacts on rice production at Satkhira, Bangladesh," Pakistan Journal of Meteorology, vol. 6, no. 11, pp. 37-50, 2014.

[12] E. R. Dahmen and M. J. Hall, Screening of Hydrological Data: Tests for Stationarity and Relative Consistency, Publication \#49, ILRI, Wageningen, The Netherlands, 1990.

[13] Q. Zhang, C. Liu, C.-Y. Xu, Y. Xu, and T. Jiang, "Observed trends of annual maximum water level and streamflow during past 130 years in the Yangtze River basin, China," Journal of Hydrology, vol. 324, no. 1-4, pp. 255-265, 2006.

[14] H. Chen, S. Guo, C.-Y. Xu, and V. P. Singh, "Historical temporal trends of hydro-climatic variables and runoff response to climate variability and their relevance in water resource management in the Hanjiang basin," Journal of Hydrology, vol. 344, no. 3-4, pp. 171-184, 2007.

[15] H. B. Mann, "Nonparametric tests against trend," Econometrica, vol. 13, pp. 245-259, 1945.

[16] M. G. Kendall, Rank Correlation Methods, Griffin, London, UK, 1975.

[17] E. L. Lehmann, Nonparametrics, Statistical Methods Based on Ranks, Holden-Day, San Francisco, Calif, USA, 1975.

[18] R. Sneyers, "On the statistical analysis of series of observations," Technical Note 143, WMO no. 415, World Meteorological Organization, 1990.

[19] A. Longobardi and P. Villani, "Trend analysis of annual and seasonal rainfall time series in the Mediterranean area," International Journal of Climatology, vol. 30, no. 10, pp. 1538-1546, 2010.

[20] Z. Yanming, W. Jun, and W. Xinhua, "Study on the change trend of precipitation and temperature in Kunming city based on Mann-Kendall analysis," in Future Computer, Communication, Control and Automation, vol. 119 of Advances in Intelligent and Soft Computing, pp. 505-513, Springer, Berlin, Germany, 2011.

[21] X. L. Yang, L. R. Xu, K. K. Liu, C. H. Li, J. Hu, and X. H. Xia, "Trend in temperature and precipitation in the Zhangweinan River Basin during the last 53 years," Procedia Environmental Sciences, vol. 13, pp. 1966-1974, 1966.

[22] Z. F. Yang, Y. Yan, and Q. Liu, “The relationship of streamflowprecipitation-temperature in the Yellow River Basin of China during 1961-2000," Procedia Environmental Sciences, vol. 13, pp. 2336-2345, 2012.

[23] Q.-X. Wang, X.-H. Fan, Z.-D. Qin, and M.-B. Wang, "Change trends of temperature and precipitation in the Loess Plateau Region of China, 1961-2010," Global and Planetary Change, vol. 92-93, pp. 138-147, 2012.

[24] S. Yue, P. Pilon, and G. Cavadias, "Power of the Mann-Kendall and Spearman's rho tests for detecting monotonic trends in hydrological series," Journal of Hydrology, vol. 259, no. 1-4, pp. 254-271, 2002.

[25] E. Kahya and S. Kalayc1, "Trend analysis of streamflow in Turkey," Journal of Hydrology, vol. 289, pp. 128-144, 2004.

[26] Z. L. Li, Z. X. Xu, J. Y. Li, and Z. J. Li, "Shift trend and step changes for runoff time series in the Shiyang River Basin, Northwest China," Hydrological Processes, vol. 22, no. 23, pp. 4639-4646, 2008.

[27] C. Yaning, X. Changchun, H. Xingming et al., "Fifty-year climate change and its effect on annual runoff in the Tarim River Basin, China," Quaternary International, vol. 208, no. 1-2, pp. 53-61, 2009.

[28] M. Shadmani, S. Marofi, and M. Roknian, "Trend analysis in reference evapotranspiration using Mann-Kendall and Spearman's Rho tests in arid regions of Iran," Water Resources Management, vol. 26, no. 1, pp. 211-224, 2012.
[29] H. Rehman and A. Kamal, "Indus Basin River system-flooding and flood mitigation," 2005, http://archive.riversymposium .com/2005/index.php?element $=38$.

[30] Pakistan Meteorological Department (PMD), National Plan: Strengthening National Capacities for Multi-hazard Early Warning \& Response System, 2006.

[31] National Disaster Management Authority (NDMA), 2007, National Disaster Risk Management Framework, Government of Pakistan, http://www.ndma.gov.pk/new/.

[32] N. H. Hashimi, Q. T. M. Siddiqui, A. R. Ghumman, M. A. Kamal, and H. R. Mughal, "A critical analysis of 2010 floods in Pakistan," African Journal of Agricultural Research, vol. 7, no. 7, pp. 1054-1067, 2012.

[33] FFC, "Federal Flood Commission of Pakistan," Annual Flood Report-2010, 2011, http://www.ffc.gov.pk/download/flood/archieve/Annual.report2010.pdf.

[34] N. Gronewold and Climatewire, "Is the Flooding in Pakistan a Climate Change Disaster?” WMN, 2010, http://www.scientificamerican.com/article/is-the-flooding-in-pakist/.

[35] H. Hartmann and L. Andresky, "Flooding in the Indus River basin-a spatiotemporal analysis of precipitation records," Global and Planetary Change, vol. 107, pp. 25-35, 2013.

[36] S. Salma, S. Rehman, and M. A. Shah, "Rainfall trends in different climate zones of Pakistan," Pakistan Journal of Meteorology, vol. 9, no. 17, pp. 37-47, 2012.

[37] M. Hanif, A. H. Khan, and S. Adnan, "Latitudinal precipitation characteristics and trends in Pakistan," Journal of Hydrology, vol. 492, pp. 266-272, 2013.

[38] A. Imran, Q. Zaman, and M. Afzal, "Temporal trends in the peak monsoonal precipitation events over Northeast Pakistan," Pakistan Journal of Meteorology, vol. 10, no. 19, pp. 19-30, 2013.

[39] S. B. Cheema and M. Hanif, "Seasonal precipitation variation over Punjab province," Pakistan Journal of Meteorology, vol. 10, no. 19, pp. 61-82, 2013.

[40] H. Hartmann and H. Buchanan, "Trends in extreme precipitation events in the indus River Basin and flooding in Pakistan," Atmosphere-Ocean, vol. 52, no. 1, pp. 77-91, 2014.

[41] "Provincial Disaster Management Authority (PDMA, 2012) Monsoon Contingency Plan-Khyber-Pakhtunkhwa," 2012, http://www.ndma.gov.pk/Documents/Contingency_Plan/2012/ CP_KP.pdf.

[42] Snowy Mountains Engineering Corporation, Munda Dam Construction Project, Detailed Design Report, SMEC, Lahore, Pakistan, 2014.

[43] H. Alexandersson, "A homogeneity test applied to precipitation data," Journal of Climatology, vol. 6, no. 6, pp. 661-675, 1986.

[44] H. Alexandersson and A. Moberg, "Homogenization of Swedish temperature data. Part I: homogeneity test for linear trends," International Journal of Climatology, vol. 17, no. 1, pp. 25-34, 1997.

[45] T. A. Buishand, "Some methods for testing the homogeneity of rainfall records," Journal of Hydrology, vol. 58, no. 1-2, pp. 11-27, 1982.

[46] M. N. Khaliq and T. B. M. J. Ouarda, "On the critical values of the standard normal homogeneity test (SNHT)," International Journal of Climatology, vol. 27, no. 5, pp. 681-687, 2007.

[47] K. H. Hamed and A. Ramachandra Rao, "A modified MannKendall trend test for autocorrelated data," Journal of Hydrology, vol. 204, no. 1-4, pp. 182-196, 1998.

[48] B. Önöz and M. Bayazit, "Block bootstrap for Mann-Kendall trend test of serially dependent data," Hydrological Processes, vol. 26, no. 23, pp. 3552-3560, 2012. 
[49] M. Yaseen, H. A. Bhatti, T. Rientjes, G. Nabi, and M. Latif, "Temporal and spatial variations in summer flows of upper Indus Basin, Pakistan," in Proceedings of the 72nd Annual Session of Pakistan Engineering Congress, Paper no. 747, pp. 315-334, 2013.

[50] G. C. Blain, “The Mann-Kendall test: the need to consider the interaction between serial correlation and trend," Agricultural Engineering, vol. 35, no. 4, 2013.

[51] M. Yaseen, T. Rientjes, G. Nabi, H. ur-Rehman, and M. Latif, "Assessment of recent temperature trends in Mangla watershed," Journal of Himalayan Earth Sciences, vol. 47, no. 1, pp. 107-121, 2014.

[52] P. K. Sen, "Estimates of the regression coefficient based on Kendall's tau," Journal of the American Statistical Association, vol. 63, no. 324, pp. 1379-1389, 1968.

[53] W. S. Cleveland, "Robust locally weighted regression and smoothing scatterplots," The Journal of the American Statistical Association, vol. 74, no. 368, pp. 829-836, 1979.

[54] W. S. Cleveland, "Graphs in scientific publications," The American Statistician, vol. 38, no. 4, pp. 261-269, 1984.

[55] D. R. Helsel and R. M. Hirsch, "Statistical methods in water resources," in Techniques of Water Resources Investigations, Book 4, chapter A3, p. 522, U.S. Geological Survey, 2002.

[56] A. P. Dimri, "Surface and upper air fields during extreme winter precipitation over the western Himalayas," Pure and Applied Geophysics, vol. 163, no. 8, pp. 1679-1698, 2006.

[57] A. Ghaffar and M. Javid, "Impact of global warming on monsoon variability in Pakistan," The Journal of Animal and Plant Sciences, vol. 21, no. 1, pp. 107-110, 2011.

[58] G. Rasul, "Climate Data and Modelling Analysis of the Indus Region," Pakistan Meteorological Department (PMD), 2012, http://wwfpak.org/ccap/pdf/Climate_Data_Modelling\%20Analysis\%20of\%20the\%20Indus\%20Ecoregion.pdf.

[59] A. Basistha, D. S. Arya, and N. K. Goel, "Analysis of historical changes in rainfall in the Indian Himalayas," International Journal of Climatology, vol. 29, no. 4, pp. 555-572, 2009.

[60] P. G. Baines, "The late 1960s global climate shift and its influence on the Southern Hemisphere," in Proceedings of 8 ICSHMO, pp. 1477-1482, INPE, Foz do Iguaçu, Brazil, 2006.

[61] K. Duan and T. Yao, "Monsoon variability in the Himalayas under the condition of global warming," Journal of the Meteorological Society of Japan, vol. 81, no. 2, pp. 251-257, 2003.

[62] U. S. Nair, R. O. Lawton, R. M. Welch, and R. A. Pielke Sr., "Impact of land use on Costa Rican tropical montane cloud forests: sensitivity of cumulus cloud field characteristics to lowland deforestation," Journal of Geophysical Research D, vol. 108, no. 7, pp. 4206-4219, 2003.

[63] R. Avissar and D. Werth, "Global hydroclimatological teleconnections resulting from tropical deforestation," Journal of Hydrometeorology, vol. 6, no. 2, pp. 134-145, 2005.

[64] R. A. Pielke Sr., J. Adegoke, A. Beltrán-Przekurat et al., "An overview of regional land-use and land-cover impacts on rainfall," Tellus B: Chemical and Physical Meteorology, vol. 59, no. 3, pp. 587-601, 2007.

[65] N. Ramankutty, C. Delire, and P. Snyder, "Feedbacks between agriculture and climate: an illustration of the potential unintended consequences of human land use activities," Global and Planetary Change, vol. 54, no. 1-2, pp. 79-93, 2006.

[66] V. Ramanathan, C. Chung, D. Kim et al., "Atmospheric brown clouds: impacts on South Asian climate and hydrological cycle," Proceedings of the National Academy of Sciences of the United States of America, vol. 102, no. 15, pp. 5326-5333, 2005. 

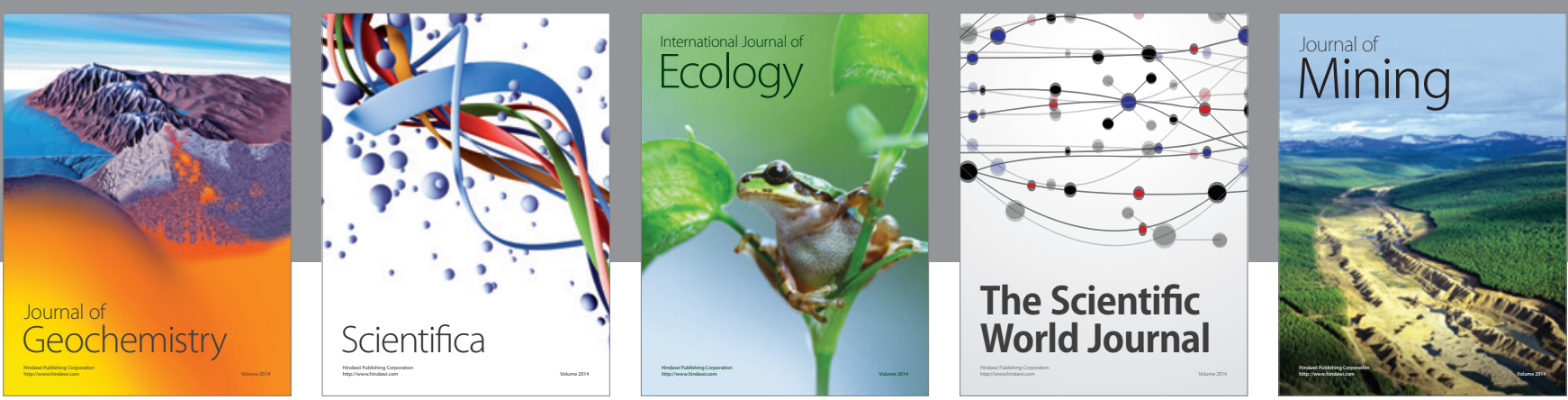

The Scientific World Journal
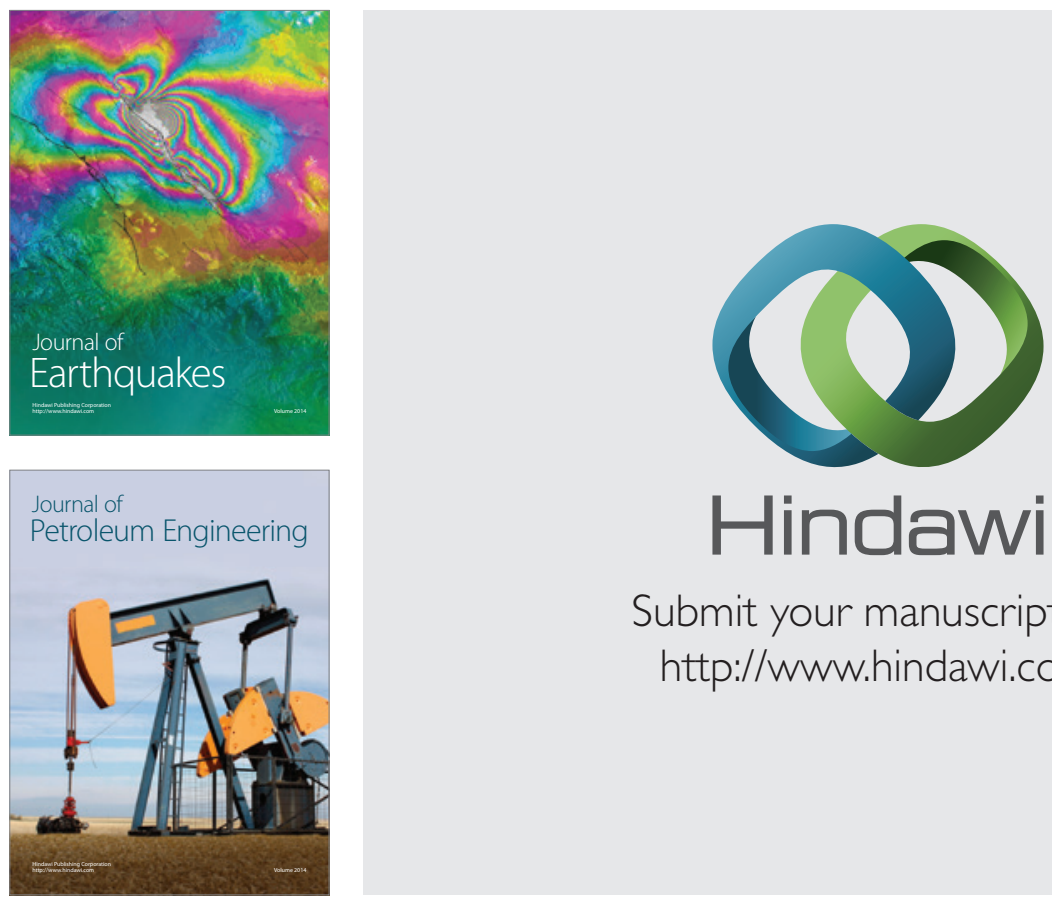

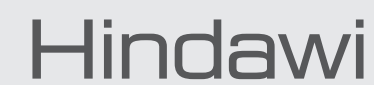

Submit your manuscripts at

http://www.hindawi.com
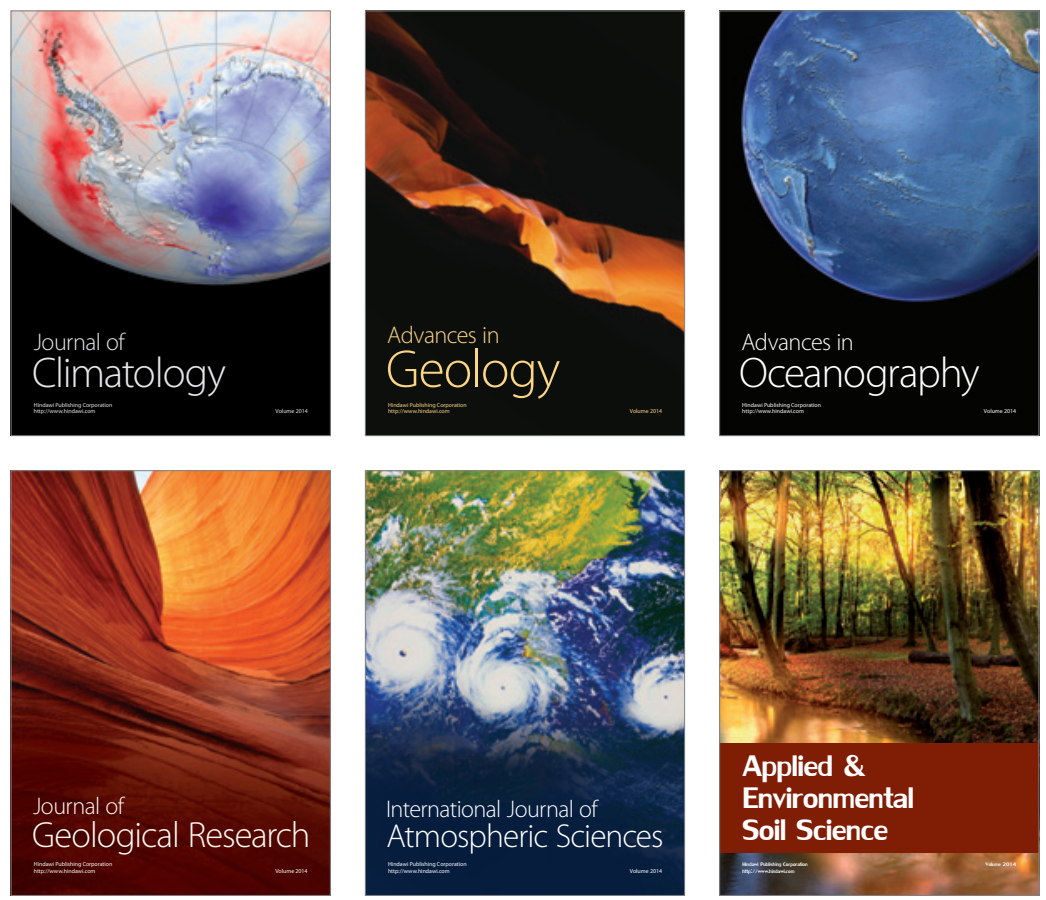
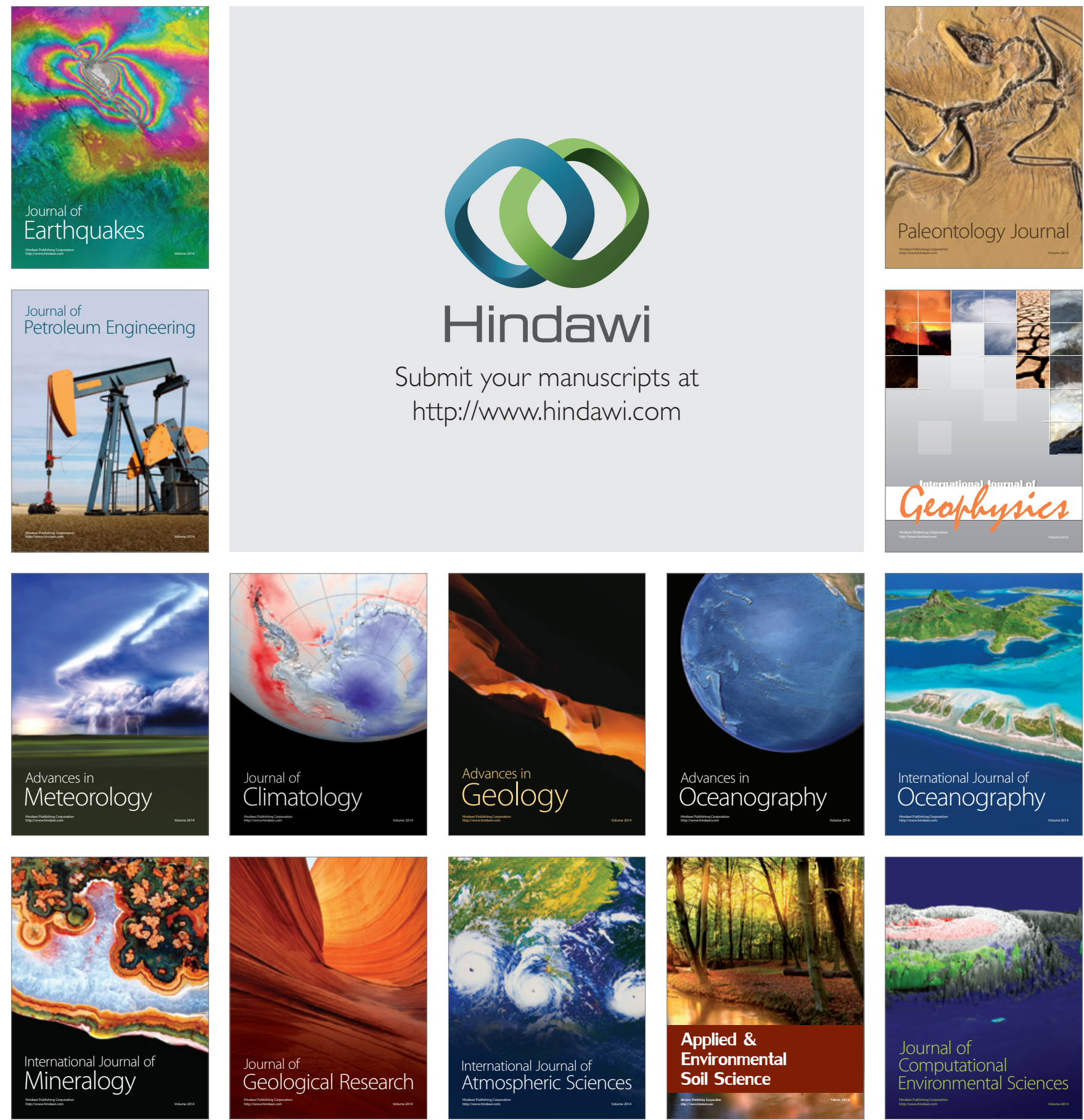